HStud 22 (2008)1-2, 103-117

DOI: 10.15566/HStud.22.2008.1-2.8

\title{
THE FIRST DECADE OF THE HUNGARIAN DANCE HOUSE MOVEMENT IN TRANSYLVANIA: A SUBJECTIVE HISTORY
}

\author{
LÁSZLÓ KELEMEN \\ Hungarian Heritage House, Budapest \\ Hungary
}

\begin{abstract}
The rise of the Hungarian Dance House Movement in Transylvania had both cultural and political implications. As an expression of interest in ethnic or national traditions, it constituted in part a gesture of resistance to the official cultural politics of communist Romania. This article offers a personal narrative of the growth and development of the dance house movement under these precarious circumstances.
\end{abstract}

Keywords: dance house, táncház, Hungarian folk dance, local culture, urbanization, communism, Romania, Transylvania

\section{Private History}

I became a folk musician by sheer chance in the summer of 1979 on the stairs of the Cluj (Kolozsvár) Academy of Music. Fate greeted me in the person of András Tőtszegi ("Cucus"), a folk dancer from Mera (Méra), who, together with Alpár Kostyák, asked me to learn to play the viola, as there was nobody at the local dance house who could. Their two former viola players, Alpár Kostyák and András Sinkó, were both in their final year of study at the Academy of Music and would soon be graduating and leaving. I had just been admitted to the Academy and thus felt rather euphoric. Happy as I was, I promised to learn to play the viola right away. Satisfied with the success of their recruitment efforts, Cucus and Alpár immediately took me to Zoltán Kallós, who was to equip me with a viola, since I did not have one at the time. While "Uncle Zoli," as everybody called him, was looking for a viola, his mother offered me cabbage soup. I finally got a huge, red, and quite roughly constructed "joiner's viola," which was too big to fit in a case, so Uncle Zoli gave me a haversack in which I could carry it. After this I skipped an entire year, doing my compulsory military service before entering the university. The summer after my year in the army I went to the first folkdance camp in Gyimes in Eastern Transylvania, where I met all the key persons of the dance house movement, such as Zoltán Kallós, Ádám Könczei and Ádám Katona 
from Odorheiu Secuiesc (Székelyudvarhely), as well as several of my fellow musicians. After this there was nothing to stop me: folk music has become a vital part of my life, all thanks to the Transylvanian dance house movement.

As I was born in the Transylvanian countryside, this might seem something of a surprising statement for me to make. I was born into a traditional Székely peasant family, so I was in close contact with Transylvanian folk culture. My walk of life can be considered typical, since at that time many village children were raised, as I was, on the ruins of the disintegrating rural civilization, being suppressed by forced urbanization.

My grandparents lived according to traditional peasant culture, and wanted to pass this on to their descendants. But my parents already turned towards the new urban way of life. I grew up on this line of rupture: my grandparents' generation wanted to adhere to cultural traditions in their entirety, but my parents' generation, though having inherited these traditions, did not want to be part of traditional culture anymore.

My first musical instrument, which I began to play at the age of four, was my grandfather's zither. My grandmother regularly took me to different social singing occasions. I was there with my first fiddle among my grandparents' friends and tried to play music as they were singing traditional tunes. My parents on the other hand bought a record-player and listened to the newest pop songs at their social gatherings.

I grew up in the 1960s, when due to forced urbanization and the creation of the collective farming system many people thought it preferable to move to large cities. They still regularly visited their native villages on holidays, but their children wanted to get rid of the traditions, perceived as outdated and old-fashioned, of their parents. I myself experienced this as a child, since my father's sister had moved to Miercurea-Ciuc (Csíkszereda), a larger town. When her children came to visit us they wore urban clothes and brought factory-made toys with them. They looked down on us, village kids, and thought we were provincial.

Many people chose to commute instead of moving to the cities. My father commuted to Miercurea-Ciuc. As a result of this he had a chance to earn a better living than most of our peers in the village community. We got a television set quite soon, as this was a measure of urban civilization at that time. It was humorous and rather symbolic to see aunt Rózsa once, our eighty-year-old neighbor, yelling at the "little people" to come out of the television box.

I lived in this dual culture until the age of ten, at which point some teachers from the Târgu Mureș (Marosvásárhely) High School of Arts came to our village as sorts of talent scouts and suggested to my parents that I study music on a scholarship in Târgu Mureș. For a long time I lived detached from peasant culture. I became "colonized" by classical music and spent my holidays back in my home village as if I were some distinguished foreigner. This was not even changed by the 
fact that sometime in 1977 some boys in my high school class began to play some unusual folk tunes, and the Hungarian division of Romanian Television began to broadcast a program entitled "Kaláka", which focused on our local traditions.

I mention all this because my personal view of the Transylvanian dance house movement is rather typical. Many of my fellow musicians and ethnographers have life-stories quite similar to mine. Most of us have rural roots, but it was the Transylvanian dance house movement that made us realize what a treasure our traditions are.

\section{The Origins of the Transylvanian Dance House Movement}

\section{Founding}

One of the vanguards of Transylvanian folklorism and the dance house movement, Ádám Könczei, gives the following account of its origins:

The birth of the dance houses is closely connected with theater and especially with school performances. There was a growing demand for a truly authentic presentation of the local traditions on school stages, instead of the fake-folk shows that had often been presented at school celebrations. It was a very sensible initiative of High School number 3 in Cluj to establish a cultural exchange with the school of (Sic) Szék, a nearby central Transylvanian village. Although this connection did not become a permanent one, it was still quite consequential. It was significant that stage performance was not the only purpose of studying the dances of Sic. Propagation and teaching of these dances in wider circles was also an aim.

However, the lack of live musical accompaniment was a great hardship that eventually put an end to the initiative. This failure was in turn a factor that led to the formation of the dance house music bands. The high-school literature teacher Éva K. Tolna invited her music students to several school performances. As a result of this, the boys (Pál Havaletz, Botond Kostyák, and Árpád Könczei) formed a flute band, although none of them majored in flute playing. Their interest in authentic instrumental folk music gradually increased, partly due to the encouragement they got from their families. The band switched to a flute (Könczei), viola (Kálmán Urszuly) and cello (Havaletz) configuration, and kept it for quite a long time, but this also proved to be but a step towards the formation of an authentic folk band. In 1976 the band finally decided in favor of the authentic representation of Transylvanian folk music. In order to carry out their plans, they began a thorough and meticulous process of study. They consulted László Lajtha's notes on authentic village music and frequently visited rural folk musicians to make recordings and to join them playing. The actual dance house opened on a Thursday in Feb- 
ruary of 1977 at the club of the Cluj Puppet Theater, due to the hospitality of Ildikó Kovács, director of the Puppet Theater, who, together with László Szabó, leader of the County Cultural Committee, was a constant and steadfast supporter of the dance house movement through all the hardships it experienced. The first dance house music band consisted of Levente Székely (fiddle), Árpád Könczei (flute, song- and dance master), Kálmán Urszuly (viola) and Antal Porzsolt (double bass). From then on there was a dance house every Thursday. For a short time it was held in the Vasas Community Center and later it moved to the Monostori Community Center. The first dance house band struck its audience as something completely new, since their music was of a different quality than the popular music of cities. It was likened to the music of Ferenc Sebő and his folk band in Hungary (Könczei, 5).

The first music band later expanded, and eventually split into two. One consisted of Dezső Sepsi (fiddle, $3^{\text {rd }}$ year college), András Sinkó (viola, $2^{\text {nd }}$ year college), and Árpád Könczei (double bass, senior high school). The members of the other band were József Székely and István Papp (fiddle, senior high school), Alpár Kostyák, (viola, 1st year college), Antal Porzsolt (double bass, $1^{\text {st }}$ year college).

The only person Ádám Könczei (1926-1982) left out from his article was himself, though he played a pivotal role in the formation of the Transylvanian dance house. His devotedness as a folklorist, his uncompromising Protestant faith, his experience in team-building, and his steadfast Hungarian ethnic identity all predestined him to the invaluable organizing activity he carried out in support of the Transylvanian dance house movement. He was fully devoted to the cause of the Transylvanian dance house. He published on it, organized it, and took part in dance house occasions as frequently as he could. Through his children he also played a decisive role in the development of the Cluj dance houses and in the development of Transylvanian folklorism. It is no wonder that the Securitate (Departamentul Securitătii Statului), the secret police force of the Communist Romania, held him as well as Zoltán Kallós to be a dangerous person. He was constantly monitored. The secret reports of the Securitate on the leading figures of the Transylvanian dance house movement have been published on Csilla Könczei's (his daughter) blog (http://konczeicsilla.egologo.transindex.ro/).

According to István Papp, one of the founders of the Cluj dance house:

That February saw the first Transylvanian dance house ever. I remember this quite clearly, since I took part in it as a dance instructor. My mother is from Suatu (Magyarszovát), a Central Transylvanian village, and as a child I spent most of my school breaks with my mother's family there. My classmates and fellow musicians, Levente (József) Székely and Árpád Könczei, knew this, so thinking that I had a certain background knowledge of Central Transylvanian 
dances, they asked me to learn the dances of the men from Sic, whom we invited to the dance house, and to teach their dances on subsequent occasions (Papp, CD-booklet, 2).

Ádám Könczei's account does not mention a parallel initiative, which was carried out as a joint venture of Visszhang [Echo] Radio and the Students Union at the University of Cluj. This endeavor in turn encouraged many other Transylvanian cities to join the dance house movement. In István Pávai’s opinion, these initiatives led to the later formation of the first dance houses in the Székely Land:

\begin{abstract}
These occasions were organized by the editors of the Hungarian radio of the Cluj Students Union, led by Miklós Patrubány. First these nights were held at the club of the Faculty of Philology, and later they moved to the clubs of other faculties. This was also the place where Katalin Panek sang Transylvanian folk ballads at that time, István Pávai, József Simó (who later became members of the "Barozda" folk music band) and Imre Kostyák (brother of the dance house musicians Attila and Alpár Kostyák) held public debates about folk art and folk music, and Dezső Sepsi sang folk songs. The discussion went beyond the public occasions: it went on even behind the scenes as to what band could provide authentic musical accompaniment for Katalin Panek. Eventually a village band was taken to the TV shooting in Bucharest. The "Harmat" ensemble was soon joined by the fiddler Dezső Sepsi and Erzsébet Zakariás, who learned to play the gardon. In the fall of 1976 they performed their Gyimesi Csángó song suite (Gagyi, 8).
\end{abstract}

This parallel initiative presents another folklorist dynasty in Cluj: all six sons of the Kostyák family became musicians, and together with the Könczei dynasty they played a vital role in the formation and development of the Transylvanian dance house movement. Naturally some rivalry between the two dynasties was inevitable, but they always joined in cooperation if the cause of the dance house was at stake.

As can be seen from the above accounts, the dance house movement initially centered around musicians, especially the students of the Cluj Academy of Music.

\title{
The Rise of Dance Houses
}

There are several features of the Transylvanian dance house movement that make it different from the parallel movement in Hungary. Naturally, the occasion to have a good night out and make new acquaintances was quite enjoyable. The dance house also presented us with a sensible and valuable pastime. As I had only studied classical music before, learning the language of folk music constituted a considerable challenge to me. Being a folk musician also posed the possibility of 
traveling abroad, which was otherwise impossible under Ceaușescu's regime. These were all quite obvious advantages of our activity; however, the most vital feature of it was the maintenance and preservation of our Hungarian culture in the ethnic minority position in which we lived.

\title{
The "Hungarian Connection"
}

Although it was not a thing to advertise widely, it was obvious that there was an analogy between the Transylvanian dance house movement and the similar movement in Hungary, initiated by the musicians Ferenc Sebö and Béla Halmos. The connection is marked by the time-lag between the two, as well as by several references of Transylvanian folklorists to the leading figures of the Hungarian dance house movement. Könczei's reference to Sebő's music has already been cited. In his book entitled Barozda, István Pávai comments:

\begin{abstract}
Zoltán Hajdú participated in a dance house camp in Székesfehérvár, Hungary in 1976, where he contacted Ferenc Sebő and Béla Halmos. Back at home, in his high school, he and Erzsébet Győrfi listened to Sebő records to reproduce its songs and also tried to launch a dance house at the high school (Pávai, 35).
\end{abstract}

Still, the connection between the Hungarian and Transylvanian dance house movements was initially sporadic and occasional, since it was hard to travel abroad from Romania in the 1970s, even though that was a period of thaw compared to the system of the $1980 \mathrm{~s}$.

The Hungarian connection was initially facilitated by the travels undertaken by Hungarian ethnographers with the purpose of collecting folk songs in Transylvania in the 1960s. The work of György Martin, Ferenc Pesovár, Bertalan Andrásfalvi, Tamás Hofer, Ferenc Novák or Sándor Tímár would have been impossible without the numerous local contributors who offered their assistance. Zoltán Kallós was glad to take the role of a constant assistant, and many ethnographers, especially György Martin, made friends with the villagers of Kalotaszeg region in Central Transylvania. These villagers had also helped Kallós survive the years of hardship after his release from prison. These eminent Hungarian scholars thoroughly followed the development of the Transylvanian dance houses and helped with whatever they could: they gave advice and also financial assistance (in the form of technical equipment and data media). In the course of their collecting tours in Transylvania they paid regular visits to Cluj after the inception of the dance house there. They were followed by representatives of the first generation to grow up with the Hungarian dance houses. The musicians Péter Éri, Sándor Csoóri Jr., László Porteleki, Csaba Ökrös, and the dancers Antal Fekete "Puma", 
László Diószegi, Zoltán Zsuráfszki, and Zoltán Varga all became regular visitors of Transylvanian dance houses. Being younger, they obviously made friends with their peers, who had been brought up in Transylvanian dance houses. This connection resulted in several enduring friendships and intimate relationships between the members of two dance house movements. The Ceaussescu regime did not weaken these strong personal bonds, but rather in some cases even strengthened them. Our friends from Hungary who worked at the Institute for Musicology of the Hungarian Academy of Sciences (in particular György Martin) gave us invaluable assistance. We got a recorder, a continuity desk, and regular raw material, all of which were great treasures in those days. In return, they regularly smuggled our folk song collections out of Romania and deposited them in the Archives of the Institute for Musicology of the Hungarian Academy of Sciences.

\section{Unique Transylvanian Features}

Alongside the similarities that it shared with the Hungarian dance house movement, the Transylvanian initiative bore aspects that made it highly different from that in Hungary.

\section{Living as an Ethnic Minority}

The 2-2.5 million Hungarians living in Transylvania were the largest European ethnic minority in those days. Their strong ethnic identity and organized system of cooperation was a constant annoyance to the antidemocratic communist regime in Romania. However, in the second half of the 1960s and throughout the 70 s the formerly penetrating oppression thawed slightly for a time. After the forced collectivization of village society, the abolition of Hungarian ethnic and administrational autonomy, and the closing of the only Hungarian University in Transylvania, the Romanian communist system had to justify itself and its unique management of foreign affairs with the introduction of a relative political laxness in its formerly rigid and highly oppressive system. Luckily, the dance house movement emerged in this period. In the course of its seventy years of existence as a minority, Transylvanian Hungarian society had learned that the preserving and cultivation of its cultural heritage is the key to survival as a distinct ethnic group. Dance house emerged as an opportunity to maintain Hungarian cultural heritage and as an original means of strengthening Hungarian ethnic identity. As in Hungary, the Transylvanian Hungarian cultural elite also welcomed this initiative and strongly supported it. We had a vivid connection with the opposition organization 
called "Ellenpontok" (Counterpoints), and there were dance house occasions in László Tőkés's flat in (Dej) Dés.

Unlike in Hungary, where the Balkan, Greek and Gypsy dance houses soon emerged as "mutations" of the Hungarian dance house initiative, the Transylvanian dance house movement remained unified and concentrated fully on local Hungarian peasant culture. We chiefly learned and popularized traditional Hungarian folk music and dances, incorporating little Romanian, Gypsy and urbanized culture into our repertoire. As is natural for minority initiatives, we soon attracted the suspicion of the governing bodies and of the Securitate. Our plan to encourage our Romanian friends to organize similar dance houses based on their culture also failed. What is more, we were often accused of having stolen Romanian folklore.

\section{Relationship with Village Musicians and Dancers}

The chance to have a close relationship with the last "great generation" of village musicians and dancers is another feature that differentiates the Transylvanian dance house movement from the one in Hungary. Although dance house occasions took place in the larger Transylvanian cities, folk culture was still vivid in the surrounding villages. This provided us with a chance to learn the skills of the trade directly from the greatest masters of folk art. People from Sic, musicians from Palatka, and Sándor Fodor "Neti," the outstanding fiddler of the Kalotaszeg region, were regular guests at our dance houses in Cluj. This connection worked vice-versa too: we also frequented village celebrations, where we had the chance to join the villagers dancing and playing music. First we went as a band, for instance playing for a wedding party in Suatu, together with the "Barozda" band. Later we also went one-by-one. I personally had built a close artistic companionship with Sándor Fodor "Neti." We played together in many wedding parties, balls and spring folk festivities. On these visits we also collected local music and dance. The memory of a wedding party in Sânmartin (Szépkenyerüszentmárton) lingered in my mind as especially memorable, as did another in Bodonkút, where I had the only chance of my life to see a "ritka magyar" ("slow Hungarian") men's dance from the Kalotaszeg region. András Tötszegi "Cucus" contacted the best village dancers and videotaped their dances.

Villagers frequented our dance houses in Cluj from the very beginnings. It was not only the youth of the nearby village Sic who came, but also were young danc-

ers commuting to Cluj from other surrounding places. According to Ádám Könczei: 
The dance house in Cluj boasts an invaluable feature in comparison with the dance houses in other Transylvanian cities: while most of the other dance houses are detached from the culture in which they are rooted, the Cluj dance house comprises both original village artists and their urban followers. These occasions therefore provide an opportunity for constant cultural exchange. Urban youth have the chance to see the breathtaking men's dances performed by István Filep or János Csorba, and can learn the dances directly from their clearest sources, as well as compare the urban dance teacher's movements and style with its original version. However, the most significant effect of this cultural exchange between rural and urban youth is its democratic unifying power. Their frequent meetings at the Cluj dance house establishes a free and easy relationship between members of very different social layers: university students, village youth and young workers made friends with one another as if they all had come from the same place (Könczei, 5).

The proximity of living folk culture was an advantage all newly-formed Transylvanian dance houses wanted to utilize. In Miercurea-Ciuc, for example, the nearby music and dance of Upper Csík (Felcsík) was a constant program of all the dance house occasions, just as the local "marosszéki" dances were in Târgu Mureș (named after the Hungarian name of the city) and the Gagy dances were in Odorheiu Secuiesc.

\section{Media}

The 'Kaláka' programs of the Hungarian broadcast of Bucharest Television and the later dance house festivals both played a significant role in popularizing dance house culture. Dance houses and the "Kaláka" television program were regular topics in the press too: opinions about them varied towards both extremes (Pávai, 26).

Zoltán Csáky and Katalin Simonffy, the editors of the TV program, were efficient not only in popularizing the movement, but also in unifying it. As Simonffy put it:

Our aim is to create a healthy mass movement! Why can't we dance Széki and Szováti folkdances [dances named after the Hungarian names of the towns from which they are known, Sic and Sovata or Szék and Szováta in Hungarian] at our parties in the city? They could fit just as well alongside the modern dances, couldn't they?

It is the noble responsibility of the directors of community centers and youth clubs, as well as of dance teachers and musicians, to shape the image of the new-born Transylvanian dance house movement. We, at the Hungarian broadcast of Romanian Television, want to 
contribute to this activity by showing this phenomenon to wider circles, and by shaking up the ones who are reluctant to move (Simonffy, 4).

In addition to the Hungarian broadcast that took place once in a week on the only Romanian television channel, the radio and the press were also significant and efficient means of publicizing the dance house movement. The Hungarian press in Cluj took a leading role in this, with special respect to the monthly Korunk (Our Age), for which Ádám Könczei worked, and Utunk (Our Way), the only Hungarian weekly paper in Cluj in those days. The weekly Hungarian edition of Ifjúmunkás (Young Worker), the paper of the Communist Youth League, is also worthy of mention. In addition to publishing widely about dance houses, the Youth League organized poetry readings called "Young workers' matinees" and regularly invited dance house groups to perform as part of these occasions.

Thanks to Piroska Demény and Zoltán Borbély, we were able to record demos at the local offices of the Cluj and Târgu Mures regional radios. Electrecord, the only Romanian record producer company, initially allowed us to make recordings of original folk performers and dance house musicians.

\section{The Outplacement System}

The spreading of the dance house movement was aided not only by the media and an encouraging Hungarian intellectual atmosphere, but (against its own will) by the Romanian administration itself. Following their graduation from university, young professionals were assigned three-year internships at a location prescribed by the administration. This system enhanced the exchange of intellectuals on a national level: Hungarians were displaced from Transylvania to territories in which the overwhelming majority of the inhabitants were Romanian, while Romanian intellectuals were forced to move to the Hungarian-inhabited parts of Transylvania. This however had a positive effect on the dance house movement. As there were two other music academies in the country, both in the Romanian parts, graduates of the Cluj Academy were allowed to stay inside Transylvania, where they were able to continue their dance house activity. This is how István Pávai, József Simó, Alpár Kostyák, and Zoltán Szalay all ended up in Miercurea-Ciuc to form the "Barozda" folk music band. András Sinkó got to Târgu Mureș and Attila Kostyák to Satu Mare (Szatmárnémeti), where they both continued to play dance house music.

This in turn meant that the Cluj dance house needed more and more new musicians every year to replace the ones who had graduated and left. This is how I became part of the "recruitment scene" described in the beginning of this article. 


\section{Schools}

Compared to the situation in Hungary, the attitude of high schools and universities towards the growth of the dance house movement in Transylvania was quite different and much more favorable. While at Budapest universities, especially in the Department of Ethnography, dance house activity was not entirely welcome, we in Transylvania met with our teachers' complete support. Hungarian and Romanian folklore was a part of our core curriculum, and our teachers always welcomed questions on these topics. Professor Ilona Szenik even organized trips for us to collect folklore.

We tried to use our connections with high schools in order to promote dance house culture there. The Hungarian high school system was so developed and well-organized in Transylvania that Romanian educational politics were not able to strangle it, though they kept a close eye on Hungarian high schools. We therefore cautiously disguised our dance house occasions as tea parties, quiz nights and club meetings. Our centers were the Ady High School in (Oradea) Nagyvárad, High School no. 3 and Brassai Sámuel High School in Cluj, Bolyai High School and the High School of Arts in Târgu Mureș, the Teacher-Training College in Odorheiu Secuiesc, and several high schools in Miercurea-Ciuc and Sfântu Gheorghe (Sepsiszentgyörgy). Students of these schools were regular participants in the Kaláka television program and formed the core of the dance houses in their local communities.

\section{Centers, Exoduses, Festivals}

Due to its favorable location, its central role in education, and the presence of talented and devoted leaders (such as Kallós and Könczei), Cluj was the cradle of the Transylvanian dance house movement. It was soon joined by other big Transylvanian cities, such as Miercurea-Ciuc, Târgu Mures, Odorheiu Secuiesc, and later Sfântu Gheorghe. Assigned positions across the country following their graduation, young Hungarian professionals tried to establish dance houses in several other cities too, but the local conditions, the gradually increasing state prohibition, and people's fear and indifference all worked against their plans. Dance house goers of the central cities were happy to take all invitations and charged no fee for their visits. The complete dance house movement operated on a non-profit basis anyway. Everybody did their work out of goodwill and for no money. Those of us from Cluj went to hold dance houses in Dej, Turda, Huedin (Bánffyhunyad) and Oradea (Nagyvárad), while our fellows in Miercurea-Ciuc visited Sfântu Gheorghe and Odorheiu Secuiesc, occasionally going as far as (Gheorgheni) Gyergyószentmiklós. 
From the very beginning we were keen on organizing dance house festivals, where the dance house communities of different cities could meet. Our festivals between 1978 and 1982 were hosted by Odorheiu Secuiesc, and there was a festival in Cluj once too. We initially managed to win the benevolence of the Communist Youth League of the Hungarian-inhabited Hargita County, in which Odorheiu Secuiesc is also located. As a result of our initial cooperation (which was later ruined becauase of political manipulations), we organized our first and only folkdance camp in Lunca de Sus (Gyimesfelsőlok) in Hargita County.

\section{Transylvanian Dance Houses Go Underground}

\section{Dance Houses and the Securitate}

Zoltán Kallós, Ádám Könczei, and Ádám Katona, the founding fathers of the Transylvanian dance house movement, had unclear records at the "Securitate," so their activity around the dance houses soon aroused the suspicions of the Romanian secret police. Espionage was present in the dance houses from the very beginnings. All our moves were being monitored, and many reports were compiled. Under these circumstances it was a miracle that there was even a period when we were able to organize dance houses relatively freely. Pressure was initially exerted upon our leaders. Then it gradually spread to any of us who had made some contribution to the dance house movement, leading to the never-ending, humiliating process of generating fear: summons, being forced to make a declaration, being roped in, refusing, and being punished. Each of us had his or her personal story of harassment by the Securitate. Sometimes we told our stories to one another in small circles to release the anxiety that had accumulated in us.

I offer the following true story as an illustration of the situation in which we had to live. On New Year's Day, 1982 three dance house goers set off from Cluj to go on a collecting trip to Moldova, where the easternmost groups of Hungarians live. On their way they were joined by a Hungarian girl who was an American citizen. They got gas (which was impossible to get at gas stations) and traveled East to Moldova. On the second day of the trip they were raided and taken to the nearest office of the Securitate in (Bacău) Bákó. They were deprived of all their official documents, recorders and cameras, and were interrogated separately for the whole day, then sent off to sleep in a local hostel without their documents. This continued the next day. On the morning of the third day it occurred to one of them that he had a spare key to their car. They decided to flee. They set off, but chose a long and complicated route, since they knew the roads were being monitored too. They stopped on their way to put the American girl on a train to Bucharest, where she hoped to ask for refuge in the American Embassy. After making several loops 
on their way, the others finally got to Târgu Mureș, where they first called an acquaintance who was a lawyer, then visited the Hungarian writer András Sütö to ask for his advice. As they said goodbye to Sütő, they were arrested by Securitate officials waiting for them outside the writer's house. They were immediately taken to the commander-in-chief of the Marovásárhely Securitate. There they were first asked about the location of their American companion. On learning that she was planning to seek refuge at the American Embassy, the officers became infuriated. A series of lengthy telephone calls began, which strangely calmed the officers down. In a much more civil manner, they told the three young people to go back to Bákó for their documents and to "kindly forget about" the whole affair. They even got gas in their car for the ride. Under police escort, they drove to Bákó in the constant fear of being pushed into the abyss by the accompanying police cars. It was later that they learned that the American girl had saved their lives. She had made it to the Embassy, where she had met Tom Lantos, who was to meet with Ceauşescu the next day. Learning what had happened with the girl and her companions, he strongly protested against such treatment. It was at his intervention that the three young people were released without any major repercussions. However, from then on they never got passports and their activity was closely observed.

This story is meant to illustrate the circumstances in which we had to work in those days. Even simple dance house goers were monitored. The enormous intimidating mechanism started to grind up the enthusiasm, nerves and personal relationships of those who wanted to promote a vibrant Hungarian folk culture in Transylvania. This process ultimately ended in a ban on all dance house activity and the intimidation and sanctioning of its devotees.

In her blog Csilla Könczei published one of the plans for the abolition of dance houses. We have no reason to doubt that the systematic obliteration of the Transylvanian dance houses between 1984-1986 was carried out on the basis of quite similar plans. In order to "finalize the dance house issue", captain Ghiuruțan outlined the necessary course of action in seven points.

Regarding the virulence and extent of the case, we find it necessary to launch an informative-operative action. We wish to carry it out in cooperation with respective institutions of education, and as a result, wish to neutralize the harmful activity of the persons concerned. Therefore, in accordance with the 000875/15.05/1976 decree of the Ministry of Home Affairs, we recommend that

1. The local party and CYL (Communist Youth League) bodies be informed in order to induce the necessary action of the Socialist Cultural and Educational Committee of Kolozs County. Necessary action means the obliteration of this movement, and the creation of an 
appropriate political atmosphere at the dance houses on Monostori út/road and in the CFR/Vasutas Community Center.

2. Persons concerned (Könczei, Kallós) be warned [which means intimidated] in our offices.

3. The behavior of the students listed in Appendix 1. be subject of a discussion at their educational institutions, on faculty, departmental and study group levels. This process is to be aided by the Communist Youth League [in other words the students in question were to be discredited in the eyes of their professional community].

In order to make this method more effective, we see it necessary to ask the faculties for permission about the preliminary interrogation of 2 or 3 students. These students may later be used as negative examples in further actions.

4. Other students who participated in dance house activity are to be positively influenced by the deanery, professors and the Communist Youth League.

5. The Passport Office of the Ministry of Home Affairs in Kolozs County is to be informed about the deed of person living in who hosted a Hungarian citizen without permission. Action should be taken according to the 225/1975. decree.

6 . [Kallós] is to be warned in the form of interrogations and by action taken by the Socialist Cultural and Educational Committee of Kolozs County. He is to be discredited and isolated from his followers.

7. Incorporation of those who display their willingness to cooperate with us. (In other words roping in dance house goers who were willing to cooperate with the Securitate.)

The first dance house to be banned in Cluj was the one on Monostori út/road. Later, in the spring of 1984, we were expelled from the Vasutas Community Center on the pretext of redecoration. We were never able to return to any of these places.

From then on the Cluj dance house was forced into illegality. We held our meetings in private flats, only to be followed by the Securitate's regular interrogations, attempts to co-opt us, and other repercussions. With the outplacement of the first dance house generation and the intimidation of prospective supporters it became impossible to hold dance house occasions on a regular basis in Transylvania. The horrifying "deep dictatorship" and agony of the Ceaussescu regime had begun. In these years, a high percentage of the Transylvanian Hungarian intellectuals (including numerous members of the dance house movement) left their homes to settle in foreign countries, from the U.S. to Israel, in the hopes of finding a better and freer life.

In 1984 I was assigned to a position in Nagyenyed (Aiud), from where, due to continuous denunciations, harassment and the practical ban on my professional activity, I moved to Hungary in 1986. 
After the changes of 1989 the Transylvanian dance houses, much like many other things, had to be rebuilt from their ruins. But this is yet another story.

\section{Bibliography}

Gagyi, József: “Tények és kérdőjelek. A táncházmozgalomról” (Facts and question marks. About the dance house movement). Igaz Szó (1980).

Könczei, Ádám: "Tárt kapujú táncházakért" (For dance houses with open gates). Müvelödés 11 (1977).

Papp, István: “Gázsa”. Gázsa. CD, preface, ABt 1998.

Pávai, István: Barozda 1976-2001. Csíkszereda: Alutus, 2001.

Simonffy, Katalin: "Néptánc a képernyőn” (Folkdance on Screen). Müvelődés 11 (1977). 